\title{
Assessment of infection Control Precautions Among Healthcare Team in Intensive Care Units at Main Assiut University Hospital
}

\author{
Rasmia Ibrahim Abdalla, Enas Abd EL-Mageed Daef, Mona Aly Mohamed \& Mervat Anwar Abd El-Aziz. \\ Clinical Nurse Specialist, Assiut University Hospital, Assiut, Egypt. \\ Professor of Microbiology and Immunology, Faculty of Medicine, Assiut University, Egypt. \\ Assistant Professor in Critical Care Nursing and Emergency, Faculty of Nursing, Assiut University, Egypt. \\ Assistant Professor in Critical Care Nursing and Emergency, Faculty of Nursing, Assiut University, Egypt.
}

\begin{abstract}
Background: Critically ill patients are at risk of resistant infection for several reasons, including, abnormal immune systems, and invasive procedures. Assessment of infection control designed to protect healthcare team and patients from exposure to infected blood and body fluids by applying the principles of infection prevention. Aim: The study identify to assess infection control precautions among health care team in intensive care units. Design: descriptive research design utilized in this study. Setting: The study carried out in intensive care units at Main Assiut university hospital. Subjects: The study comprised assessment of 295 staff from intensive care team. A total of (31) physicians, (202) nurses and (62) workers participated. Tools: two tools utilized to collect data pertinent to the study: Tool I: - Assessment health team questionnaire for infection, Tool II: Their information infection control precautions: (observational checklist). Methods: the study conducted through preparatory, and implementation phase for assessing after practice about infection control precautions. Results: The current study revealed that there was significant statistical difference between health team assessed adequacy of infection control precautions $(61.3 \%$, 94.6\%) respectively their practice with P-value $\left(\mathrm{p}<0.000^{*}\right)$. Conclusion: Based on findings of the current study, it can be concluded that satisfactory practice level regarding infection control precautions many majority of nurses versus physicians. Recommendation: Continuous updating knowledge and practice of health care team through inservice educational programs regarding infection control precautions.
\end{abstract}

\section{Keywards: Infection, Nosocomial Infection \& Infection Control Precautions.}

\section{Introduction}

Critically ill patients are at risk of resistant infection for several reasons, including abnormal immune systems, high use of antibiotics, invasive procedures, decreased resistance to infection, nutrition, and prevalence of resistant infections in intensive therapy unit. The single most important element in preventing sepsis is infection prevention and control practice Critically ill patients are at risk of developing methicillin resistant staphylococcus aureus (MRSA) bacteraemias. (Creed \& Spiers, 2010) Global estimates the prevalence of Hospital-acquired infections (HAIs) are not available, but it has been estimated that over four million patients in Europe and 1.7 million in the US develop HAIs each year with higher prevalence in developing countries (Correa et al., 2013)

Nurses have the unique opportunity to reduce the potential for HAIs. Utilizing the skills and knowledge of nursing practice, can facilitate patient recovery while minimizing complications related to infections (Benson \& Powers, 2011)

Prevention and management of infection is the responsibility of all staff working in health care, and an integral element of patient safety programmers (Evans et al., 2012)
Infection prevention should take the priority in any setting where healthcare is delivered. This includes the availability of appropriate equipments and supplies necessary for the consistent following of the Precautions, including hand hygiene, injection equipment, and personal protective equipment (including gloves, gowns, face and eye protection) (Centers for Disease Control \& Prevention \& the Healthcare Infection Control Practices Advisory Committee, 2014).

Infection prevention and control (IPC) measures in health-care settings are of central importance to the safety of the patients, health-care workers and the environment, and to the management of communicable disease threats to the global and local community (World Health Organization, 2014)

Infection and its prevention have been the focus of much media and political attention in recent years. Critically ill patients are immunocompromised, so more susceptible to infection. One-quarter of all hospital infections occur in the intensive care units "ICUs", while more than a quarter of patients admitted to the ICUs have infections, and half of them are healthcare- associated. (Woodrow, 2012) The ultimate value of an infection control programme for patients is measured by lower rates of infection, higher rates of survival, decrease in morbidity, 
shorter periods of hospital stays, and more rapid return to health. (Burd et al., 2014)

\section{Aim of the study}

The aim of this study was to assess the infection control precautions among health care team in intensive care units at Assiut University Hospital.

\section{Significance of the Study}

It has documented in several epidemiological studies that health team such as physicians, nurses and workers are involved in the transmission of nosocomial infections. Literature that has explored the knowledge and practices of health team is limited. Therefore, it is important to investigate the impact of knowledge and practices of health team with regard to the degree of the infection control. Assessing practice with infection control measures in any health care setting is vital. Regular updating and strengthening of infection control practices should be one of the priority function of any place where health services are rendered (Fashafsheh et al, 2015)

According to the WHO, 7.1 million cases of HAI occur every year. One out of every 20 people suffers from hospital infection (Sarani et al., 2016).

\section{Subjects \& methods \\ Research design: Descriptive study. \\ Setting and sample}

Setting: The study was conducted in the ICU at Assiut university hospital as following: the digestive system ICU, general reception of emergency and critical cases, coronary care unit (CCU), blood diseases ICU, chest ICU, general ICU, postoperative ICU, and trauma ICU.

Sample: A convenient sample of physicians, nurses and workers in intensive care units for six months at the previous mentioned settings were included in this study. The study included 295 (31) physicians, (202) nurses and (62) workers working in the intensive care units .The distribution of the health care team included in the study as follows:

\begin{tabular}{|l|c|c|c|c|}
\hline \multicolumn{1}{|c|}{ Place } & $\begin{array}{c}\text { No. of } \\
\text { nurses }\end{array}$ & $\begin{array}{c}\text { No. of } \\
\text { physicians }\end{array}$ & $\begin{array}{c}\text { No. of } \\
\text { workers }\end{array}$ & total \\
\hline General ICU & $\begin{array}{c}\text { thirty } \\
\text { five }\end{array}$ & - & five & Forty \\
\hline Trauma ICU & $\begin{array}{c}\text { twenty } \\
\text { seven }\end{array}$ & - & two & $\begin{array}{c}\text { Twenty } \\
\text { nine }\end{array}$ \\
\hline $\begin{array}{l}\text { Post- } \\
\text { operative } \\
\text { ICU }\end{array}$ & sixteen & five & $\begin{array}{c}\text { Twenty } \\
\text { one }\end{array}$ \\
\hline $\begin{array}{l}\text { General } \\
\text { reception of } \\
\text { emergency \& } \\
\text { trauma" }\end{array}$ & fifty one & seventeen & twenty & $\begin{array}{c}\text { Ninety } \\
\text { one }\end{array}$ \\
\hline $\begin{array}{l}\text { Digestive } \\
\text { system ICU }\end{array}$ & thirteen & five & three & $\begin{array}{c}\text { Twenty } \\
\text { one }\end{array}$ \\
\hline
\end{tabular}

\begin{tabular}{|l|l|l|l|l|}
\hline $\begin{array}{l}\text { Blood } \\
\text { disease ICU" }\end{array}$ & six & three & four & thirteen \\
\hline CCU & $\begin{array}{l}\text { thirty } \\
\text { two }\end{array}$ & three & thirteen & $\begin{array}{l}\text { Forty } \\
\text { eight }\end{array}$ \\
\hline Chest ICU & $\begin{array}{l}\text { twenty } \\
\text { two }\end{array}$ & three & seven & $\begin{array}{l}\text { Thirty } \\
\text { two }\end{array}$ \\
\hline Total & 202 & 31 & 62 & 295 \\
\hline
\end{tabular}

Tools and data collection

Two tools were developed and utilized by the researcher to collect data pertinent to the current study: a structured interview questionnaire and nurses' performance observational checklist.

Tool 1: Health care team infection control precautions knowledge structured questionnaire:

This tool is developed by Ministry of Health and Population, 2014, to assess knowledge of the health care team regarding infection control precautions. It included 4 main parts; as follows:

Part 1: Demographic data of health care team such as (age, sex, marital status Qualifications, ICU, and years of experience), it includes 6 items.

Part 2: Health care team information about vaccination against viral hepatitis (B) for health care team such as (vaccination against viral hepatitis (B), number of vaccination doses taken, and administration of vaccination through the infection control program), it includes 3 items.

Part 3: Health care team information about exposure to needle stick injury during work for health care team such as ( injury with needle while working, causes of injury with needle, reporting about the recent injury, what did after injury, and what done before remove used needle), it includes 5 items.

Part 4: Health care team information of the availability of supplies and resources in ICUs as represented by health care team such as (presence of sinks for hand washing, number of sinks, presence of soap for hand washing, efficiently antiseptic solutions containers, appropriate antiseptic solution enough for hand washing healthy or surgical, presence of alcohol for hands rub, presence of safety box to get rid of sharp wastes, and a policy for invasive procedures), it includes 8 items.

\section{The scoring system}

Health care team "nurses, physicians, and workers" information as satisfactory or unsatisfactory level. It includes 22 questions for nurses, 22 for physicians, and 21 questions for workers. A score value of one was awarded to each correct answer and zero for wrong answer. Scores less than $75 \%$ are considered unsatisfactory information \& scores from $75 \%$ $100 \%$ are considered satisfactory.

Tool 2: Health care team practice observational checklist regarding infection control precautions:

-This tool was developed by Ministry of Health and Population, (2014) to assess the practice of the health care team regarding the infection control 
precautions. It included 4 main parts; as following procedures:

Part 1: Suction care for health care team such as (hand washing or disinfection before procedure, drying hands after washing, wearing new gloves, using sterile device or equipment, using sterile device or equipment in every suction as hospital policy, don't using touching manner during suction, changing gloves between any procedures, removal gloves after end of insertion, hand washing after removal of gloves, separate sharp wastes by good manner, and disposal of sharp wastes in sharp box), it includes 11 steps.

Part 2: Intubation patient care for health care team such as (hand washing or disinfection before procedure, drying hands after washing, wearing new gloves, using sterile device or equipment, using sterile device or equipment in every trying or insertion, changing gloves between any procedures, removal gloves after end of insertion, hand washing after removal of gloves, separate sharp wastes by good manner, and disposal of sharp wastes in sharp box), it includes 10steps.

Part 3: Total score of health care team practice for health care team such as (suction care, intubated patient care, and total score of practice), it includes 3 items.

Part 4: Health team practice for health care team such as (adequate and in adequate), it includes 2 items.

\section{The scoring system}

Health care team "nurses and physicians" practice was considered adequate or inadequate level scored as follows: correctly done was scored (2), in-correctly done was scored (1), and not done was scored (0). It includes 21 steps/items for nurses, and physicians.

The total score of checklist was classified as the following:

- Adequate level of practice is equal or more than $70 \%$ of the maximum score.

- Inadequate level of practice is less than $70 \%$ of the maximum score.

\section{Method}

The study included two main phases; preparatory and implementation phase.

\section{Preparatoy phase}

- Through which the data collection tools was prepared and tested after review the related literature.

- The tool was developed by Ministry of Health and Population, 2014 to assess the practice of the health care team regarding the infection control precautions.

- Revision of tools content, Validity from intensive care medical and nursing experts "3 staff of critical care units".
- A Pilot study was conducted on 10 nurses to test the feasibility and applicability of the tools and to estimate the time needed to fill the questionnaire.

- The Reliability was test for tool one (knowledge assessment tool) by using Alpha Cronbach's test $(\mathrm{R}=0.735)$, and tool two (Practice assessment tool) by using Alpha Cronbach's test $(\mathrm{R}=0.847)$.

- An official approval letter was obtained from Directors of intensive care units at Assiut university hospital after explanation of the purpose, contents and the nature of the study.

- Tool (1) which used in this study was developed in Arabic by the researcher based on reviewing the literature.

- Tool (2) to assess practice before, during and after patient care.

\section{Ethical considerations}

- Written consent was obtained from health teams that participate in the study, after explaining the nature and purpose of the study.

- Health care team was assured that the data of this research will not be reused without second permission.

- Confidentiality and anonymity was assured.

- Health care team have the right to participate or refuse participation in the study without any rational at any time.

\section{Implementation phase}

- Data collection was done by researcher.

- The participant health care team was interviewed by the researcher to fill in the questionnaire with the researcher-using (tool -1).

- The average time taken for completing each questionnaire was around 15-20 minutes.

- Questionnaire sheet included demographic data, training methods of infection control, vaccination, and availability of supplies and resources "tool one" "parts 1-4".

- Practice assessed using the tool (An observational checklist) was done by researcher, to assess their practice before, during and after patient care during morning, afternoon \& nightshifts.

- The observational checklist included suction care and intubation care regarding infection control precautions.

- Data collected from intensive care units during the period from May 2015 until the end of December 2015.

Statistical analysis

- The data obtained reviewed, analyzed, categorized, and tabulated by the investigator.

- The data entry was done by using compatible personal computer by the investigator. Data analysis was done using (SPSS) version 19. 
- Data presented using descriptive statistic in the form of number, percentage, mean, and standard deviation.

- Chi-square test was done to compare qualitative variables.

- Using T-test to determine significance for quantitative variables to compare between two groups.

- ANOVA test were used in this tool for more than two groups.

- Graphics were done using Excel.

- P-value considered Statistical significant difference $(\mathrm{p}<0.05)$.

\section{Limitations of the study}

Many barriers that happen during collecting data about application of infection control precautions in intensive care units for health team as some nurses asked about the value of this sheet, and some of them refused to fill forms. Many health teams "physicians" are very busy and some of them refused to fill it.

Solving the limitations

- Explaining the important of infection control precautions for health care teams.

- Continuous updating knowledge and practice of ICU health care team in-service educational programs.

- Availability of posters for reminding nurses to comply with precautions are recommended.

\section{Results}

Results of the present study demonstrate assessment of infection control precautions among the health care team in the intensive care units. The numbers of the nurses are 202, the numbers of physicians are 31 , and the numbers of workers are 62. The results presented in two parts as follows:

Part (1): Assessment of the Health Team knowledge in the intensive care units regarding infection control precautions. This part included "4 tables":

Table (I): Demographic data about Health Care Team in intensive Care units (Total number of the HCT=295).

\begin{tabular}{|c|c|c|c|c|c|c|c|}
\hline \multirow[t]{2}{*}{ Health Care Team "HCT" } & \multicolumn{2}{|c|}{$\begin{array}{c}\text { Nurses } \\
(n=202)\end{array}$} & \multicolumn{2}{|c|}{$\begin{array}{c}\text { Physicians } \\
(\mathbf{n}=31)\end{array}$} & \multicolumn{2}{|c|}{$\begin{array}{l}\text { Workers } \\
(\mathrm{n}=62)\end{array}$} & \multirow[t]{2}{*}{ P-value } \\
\hline & No. & $\%$ & No. & $\%$ & No. & $\%$ & \\
\hline Age: (years) & & & & & & & $0.000^{*}$ \\
\hline$<25$ & 98 & 48.5 & & & 7 & 11.3 & \\
\hline $25-35$ & 83 & 41.1 & 31 & 100.0 & 14 & 22.6 & \\
\hline$>35-55$ & 21 & 10.4 & & & 41 & 66.1 & \\
\hline Sex: & & & & & & & $0.000^{*}$ \\
\hline Male & 4 & 2.0 & 9 & 29.0 & 55 & 88.7 & \\
\hline Female & 198 & 98.0 & 22 & 71.0 & 7 & 11.3 & \\
\hline Marital status & & & & & & & $0.000^{*}$ \\
\hline Single & 73 & 36.1 & 22 & 71.0 & 9 & 14.5 & \\
\hline Married & 126 & 62.4 & 9 & 29.0 & 52 & 83.9 & \\
\hline Divorced & 3 & 1.5 & & & 1 & 1.6 & \\
\hline \multicolumn{7}{|l|}{ Qualification } & \\
\hline Nursing Bachelor & 28 & 13.9 & & & & & \\
\hline Nursing Technical Institute & 64 & 31.7 & & & & & \\
\hline Nursing Diploma & 110 & 54.5 & & & & & \\
\hline Bachelor medicine & & & 28 & 90.3 & & & \\
\hline Master medicine & & & 3 & 9.7 & & & \\
\hline Read and write & & & & & 21 & 33.9 & \\
\hline Primary/ preparatory & & & & & 36 & 58.1 & \\
\hline Secondary & & & & & 5 & 8.1 & \\
\hline \multicolumn{8}{|l|}{ Numbers of HCT in ICU } \\
\hline General ICU & 35 & 17.3 & & & 5 & 8.1 & 0.075 \\
\hline Trauma ICU & 27 & 13.4 & & & 2 & 3.2 & $0.026^{*}$ \\
\hline Post-operative ICU & 16 & 7.9 & & & 5 & 8.1 & 0.971 \\
\hline
\end{tabular}




\begin{tabular}{|c|c|c|c|c|c|c|c|}
\hline \multirow[t]{2}{*}{ Health Care Team "HCT" } & \multicolumn{2}{|c|}{$\begin{array}{c}\text { Nurses } \\
(\mathrm{n}=\mathbf{2 0 2})\end{array}$} & \multicolumn{2}{|c|}{$\begin{array}{c}\text { Physicians } \\
(\mathbf{n}=31)\end{array}$} & \multicolumn{2}{|c|}{$\begin{array}{c}\text { Workers } \\
(\mathrm{n}=62)\end{array}$} & \multirow[t]{2}{*}{ P-value } \\
\hline & No. & $\%$ & No. & $\%$ & No. & $\%$ & \\
\hline Reception of general emergency \& trauma & 51 & 25.2 & 17 & 54.8 & 23 & 37.1 & $0.002 *$ \\
\hline Digestive \&liver "hepatic" failure ICU & 13 & 6.4 & 5 & 16.1 & 3 & 4.8 & 0.109 \\
\hline Blood disease ICU & 6 & 3.0 & 3 & 9.7 & 4 & 6.5 & 0.161 \\
\hline Cardiac care unit "CCU " & 32 & 15.8 & 3 & 9.7 & 13 & 21.0 & 0.364 \\
\hline Chest ICU & 22 & 10.9 & 3 & 9.7 & 7 & 11.3 & 0.972 \\
\hline \multicolumn{7}{|l|}{ Years of experience } & \multirow[t]{5}{*}{$0.000^{*}$} \\
\hline$<1$ & 33 & 16.3 & 6 & 19.4 & 9 & 14.5 & \\
\hline $1-<5$ & 48 & 23.8 & 25 & 80.6 & 13 & 21.0 & \\
\hline $5-<10$ & 51 & 25.2 & & & 7 & 11.3 & \\
\hline$\geq 10$ & 70 & 34.7 & & & 33 & 53.2 & \\
\hline
\end{tabular}

$*=$ Statistical significant difference $(p<0.05)$

HCT "Health Care Team" ICU "Intensive Care Unit"

Table (2): Health Care Team information about vaccination against viral hepatitis (B) (Total number of the HCT=295).

\begin{tabular}{|c|c|c|c|c|c|c|c|}
\hline \multirow[t]{2}{*}{ information } & \multicolumn{2}{|c|}{$\begin{array}{c}\text { Nurses } \\
(n=202)\end{array}$} & \multicolumn{2}{|c|}{$\begin{array}{c}\text { Physicians } \\
(\mathrm{n}=31)\end{array}$} & \multicolumn{2}{|c|}{$\begin{array}{c}\text { Workers } \\
(n=62)\end{array}$} & \multirow[t]{2}{*}{ P-value } \\
\hline & No. & $\%$ & No. & $\%$ & No. & $\%$ & \\
\hline \multicolumn{7}{|c|}{ Vaccination against viral hepatitis (B) } & \multirow{3}{*}{0.092} \\
\hline Yes & 100 & 49.5 & 21 & 67.7 & 37 & 59.7 & \\
\hline No & 102 & 50.5 & 10 & 32.3 & 25 & 40.3 & \\
\hline \multicolumn{7}{|c|}{ Number of Vaccination doses taken } & \multirow{4}{*}{$0.037 *$} \\
\hline One dose & 16 & 16.0 & 0 & 0.0 & 11 & 29.7 & \\
\hline Two doses & 26 & 26.0 & 4 & 19.0 & 6 & 16.2 & \\
\hline Three doses & 58 & 58.0 & 17 & 81.0 & 20 & 54.1 & \\
\hline \multicolumn{7}{|c|}{ administration of Vaccination through the infection control program } & \multirow{3}{*}{$0.000 *$} \\
\hline Yes & 90 & 90.0 & 6 & 28.6 & 37 & 100.0 & \\
\hline No & 10 & 10.0 & 15 & 71.4 & 0 & 0.0 & \\
\hline
\end{tabular}

$*=$ Statistical significant difference $(p<0.05)$

Table (3): Health Care Team information about exposure to injury during work (Total number of the HCT $=295$ ).

\begin{tabular}{|c|c|c|c|c|c|c|c|}
\hline \multirow[t]{2}{*}{ information } & \multicolumn{2}{|c|}{$\begin{array}{c}\text { Nurses } \\
(\mathrm{n}=\mathbf{2 0 2})\end{array}$} & \multicolumn{2}{|c|}{$\begin{array}{l}\text { Physicians } \\
(\mathbf{n}=31)\end{array}$} & \multicolumn{2}{|c|}{$\begin{array}{c}\text { Workers } \\
(n=62)\end{array}$} & \multirow[t]{2}{*}{ P-value } \\
\hline & No & $\%$ & No. & $\%$ & No & $\%$ & \\
\hline \multicolumn{7}{|l|}{ injury with a needle while working } & \multirow{3}{*}{$0.009^{*}$} \\
\hline Yes & 151 & 74.8 & 18 & 58.1 & 35 & 56.5 & \\
\hline No & 51 & 25.2 & 13 & 41.9 & 27 & 43.5 & \\
\hline \multicolumn{8}{|l|}{ Cause of injury with needle } \\
\hline During the preparation of medication & 38 & 25.2 & 0 & 0.0 & 0 & 0.0 & $0.000^{*}$ \\
\hline Patient movement & 33 & 21.9 & 10 & 55.6 & 1 & 2.9 & $0.000^{*}$ \\
\hline $\begin{array}{l}\text { During insertion of the needle into the rubber } \\
\text { stopper }\end{array}$ & 34 & 22.5 & 8 & 44.4 & 1 & 2.9 & $0.001 *$ \\
\hline prominence a needle from the garbage bag & 0 & 0.0 & 0 & 0.0 & 19 & 54.3 & $0.000 *$ \\
\hline a needle lying on the ground & 0 & 0.0 & 0 & 0.0 & 5 & 14.3 & $0.000^{*}$ \\
\hline \multicolumn{7}{|l|}{ Reporting about the recent injury } & \multirow{3}{*}{$0.000^{*}$} \\
\hline Yes & 26 & 17.2 & 0 & 0.0 & 16 & 45.7 & \\
\hline No & 125 & 82.8 & 18 & 100.0 & 19 & 54.3 & \\
\hline
\end{tabular}




\begin{tabular}{|c|c|c|c|c|c|c|c|}
\hline \multirow[t]{2}{*}{ information } & \multicolumn{2}{|c|}{$\begin{array}{c}\text { Nurses } \\
(n=202)\end{array}$} & \multicolumn{2}{|c|}{$\begin{array}{c}\text { Physicians } \\
(\mathrm{n}=31)\end{array}$} & \multicolumn{2}{|c|}{$\begin{array}{c}\text { Workers } \\
(n=62)\end{array}$} & \multirow[t]{2}{*}{ P-value } \\
\hline & No & $\%$ & No. & $\%$ & No & $\%$ & \\
\hline \multicolumn{8}{|l|}{ What did after injury? } \\
\hline Hand washing and sterilization & 10 & 38.5 & & & 12 & 75.0 & $0.021 *$ \\
\hline What done before remove used & & & & & & & \multirow{4}{*}{$0.000 *$} \\
\hline I don't do any thing & 75 & 37.1 & 9 & 29.0 & 23 & 37.1 & \\
\hline I cover it with one hand & 61 & 30.2 & 12 & 38.7 & 4 & 6.5 & \\
\hline I cover it with two hands together & 66 & 32.7 & 10 & 32.3 & 35 & 56.5 & \\
\hline
\end{tabular}

Table (4): The availability of supplies and resources in ICUs as represented by health care team (Total number of the HCT=295).

\begin{tabular}{|c|c|c|c|c|c|c|c|}
\hline \multirow[t]{2}{*}{ information } & \multicolumn{2}{|c|}{$\begin{array}{c}\text { Nurses } \\
(n=202)\end{array}$} & \multicolumn{2}{|c|}{$\begin{array}{c}\text { Physicians } \\
(n=31)\end{array}$} & \multicolumn{2}{|c|}{$\begin{array}{c}\text { Workers } \\
(n=62)\end{array}$} & \multirow[t]{2}{*}{ P-value } \\
\hline & No. & $\%$ & No. & $\%$ & No. & $\%$ & \\
\hline \multicolumn{7}{|c|}{ Presence of sinks for hand washing } & \multirow{5}{*}{$0.000 *$} \\
\hline Yes & 64 & 31.7 & 3 & 9.7 & 22 & 35.5 & \\
\hline Yes, but not enough & 118 & 58.4 & 19 & 61.3 & 8 & 12.9 & \\
\hline Yes, but used for other purposes & 4 & 2.0 & 1 & 3.2 & 0 & 0.0 & \\
\hline $\mathrm{No}$ & 16 & 7.9 & 8 & 25.8 & 32 & 51.6 & \\
\hline \multicolumn{7}{|l|}{ Number of sinks } & \multirow{4}{*}{$0.008 *$} \\
\hline One & 115 & 61.8 & 22 & 95.7 & 15 & 50.0 & \\
\hline Two & 57 & 30.6 & 0 & 0.0 & 11 & 36.7 & \\
\hline Three or more & 14 & 7.5 & 1 & 4.3 & 4 & 13.3 & \\
\hline \multicolumn{7}{|c|}{ Soap to wash your hands beside sinks: } & \multirow{4}{*}{$0.000^{*}$} \\
\hline Yes & 33 & 16.3 & 0 & 0.0 & 23 & 37.1 & \\
\hline Yes, but not enough & 107 & 53.0 & 3 & 9.7 & 12 & 19.4 & \\
\hline No & 62 & 30.7 & 28 & 90.3 & 27 & 43.5 & \\
\hline \multicolumn{7}{|c|}{ Efficiently antiseptic solutions Containers: } & \multirow{3}{*}{$0.016^{*}$} \\
\hline Yes & 25 & 12.4 & 0 & 0.0 & 2 & 3.2 & \\
\hline No & 177 & 87.6 & 31 & 100.0 & 60 & 96.8 & \\
\hline \multicolumn{7}{|c|}{ Appropriate antiseptic solution enough for hand washing healthy or surgical } & \multirow{4}{*}{$0.000 *$} \\
\hline Yes & 25 & 12.4 & 0 & 0.0 & 5 & 8.1 & \\
\hline Yes, but not enough & 50 & 24.8 & 6 & 19.4 & 1 & 1.6 & \\
\hline No & 127 & 62.9 & 25 & 80.6 & 56 & 90.3 & \\
\hline \multicolumn{7}{|c|}{ Presences of alcohol for hands rub. } & \multirow{4}{*}{$0.000 *$} \\
\hline Yes & 50 & 24.8 & 2 & 6.5 & 26 & 41.9 & \\
\hline Yes, but not enough & 98 & 48.5 & 7 & 22.6 & 10 & 16.1 & \\
\hline No & 54 & 26.7 & 22 & 71.0 & 26 & 41.9 & \\
\hline \multicolumn{7}{|c|}{ A safety box to get rid of sharp wastes } & \multirow{4}{*}{$0.000 *$} \\
\hline Yes & 168 & 83.2 & 15 & 48.4 & 60 & 96.8 & \\
\hline Yes, but not enough & 33 & 16.3 & 12 & 38.7 & 2 & 3.2 & \\
\hline No & 1 & 0.5 & 4 & 12.9 & 0 & 0.0 & \\
\hline \multicolumn{7}{|l|}{ A policy for invasive procedures } & \multirow{3}{*}{$0.000 *$} \\
\hline Yes & 139 & 68.8 & 10 & 32.3 & & & \\
\hline No & 63 & 31.2 & 21 & 67.7 & & & \\
\hline
\end{tabular}

$*=$ Statistical significant difference $(p<0.05)$ 
Part (2): Health Care Team practice concerning the infection control precautions in ICU.

Table (5): Health Team practice regarding infection control precaution in suction care (Total number of the HCT=233).

\begin{tabular}{|l|c|c|c|}
\hline \multicolumn{1}{|c|}{ Procedures } & $\begin{array}{c}\text { Nurses } \\
(\mathbf{n = 2 0 2})\end{array}$ & $\begin{array}{c}\text { Physicians } \\
(\mathbf{n = 3 1})\end{array}$ & \multirow{2}{*}{ P-value } \\
\cline { 2 - 3 } & Mean \pm SD & Mean \pm SD & \\
\hline 1.Hand washing or disinfection before procedure & $2.00 \pm 0.00$ & $2.00 \pm 0.00$ & $0.000^{*}$ \\
\hline 2.Drying hands after washing & $1.98 \pm 0.16$ & $1.74 \pm 0.45$ & $0.000^{*}$ \\
\hline 3.Wearing new gloves & $1.01 \pm 0.12$ & $0.87 \pm 0.34$ & $0.000^{*}$ \\
\hline 4.Using sterile device or equipment & $1.99 \pm 0.10$ & $1.87 \pm 0.34$ & $0.000^{*}$ \\
\hline $\begin{array}{l}\text { 5.Using sterile device or equipment in every } \\
\text { suction as hospital policy }\end{array}$ & $1.99 \pm 0.12$ & $1.58 \pm 0.50$ & $0.000^{*}$ \\
\hline 6.Don't using touching manner during suction & $1.98 \pm 0.16$ & $1.32 \pm 0.54$ & $0.000^{*}$ \\
\hline 7.Changing gloves between any procedures & $1.95 \pm 0.23$ & $1.45 \pm 0.51$ & $0.000^{*}$ \\
\hline 8.Removal gloves after end of insertion & $2.00 \pm 0.00$ & $1.87 \pm 0.34$ & $0.000^{*}$ \\
\hline 9.Hand washing after removal of gloves & $2.00 \pm 0.00$ & $1.84 \pm 0.37$ & $0.010^{*}$ \\
\hline 10.Separate sharp wastes by good manner & $0.00 \pm 0.00$ & $0.03 \pm 0.18$ & \\
\hline 11.Disposal of sharp wastes in sharp box & $1.00 \pm 0.00$ & $1.00 \pm 0.00$ & \\
\hline
\end{tabular}

$*=$ Statistical significant difference $(p<0.05) \quad$ mean score of performance of each items

Table (6): Health Team practice infection control precaution about intubation patient care (Total number of the HCT=233).

\begin{tabular}{|c|c|c|c|}
\hline \multirow[t]{2}{*}{ Procedures } & $\begin{array}{l}\text { Nurses } \\
(n=202)\end{array}$ & $\begin{array}{c}\text { Physicians } \\
(\mathrm{n}=\mathbf{3 1})\end{array}$ & \multirow[t]{2}{*}{ P-value } \\
\hline & Mean \pm SD & Mean \pm SD & \\
\hline $\begin{array}{l}\text { 1.Hand washing or disinfection before } \\
\text { procedure }\end{array}$ & $1.99 \pm 0.12$ & $2.00 \pm 0.00$ & 0.497 \\
\hline 2.Drying hands after washing & $1.97 \pm 0.18$ & $1.68 \pm 0.48$ & $0.000 *$ \\
\hline 3.Wearing new gloves & $1.00 \pm 0.07$ & $0.87 \pm 0.34$ & $0.000 *$ \\
\hline 4.Using disinfect device or equipment & $1.99 \pm 0.12$ & $2.00 \pm 0.00$ & 0.497 \\
\hline $\begin{array}{l}\text { 5.Using disinfect equipment in every trying or } \\
\text { insertion }\end{array}$ & $1.98 \pm 0.16$ & $1.65 \pm 0.49$ & $0.000^{*}$ \\
\hline 6.Changing gloves between any procedures & $1.89 \pm 0.32$ & $1.26 \pm 0.51$ & $0.000 *$ \\
\hline 7.Removal gloves after end of insertion & $2.00 \pm 0.00$ & $1.97 \pm 0.18$ & $0.010 *$ \\
\hline 8.Hand washing after removal of gloves & $2.00 \pm 0.00$ & $1.94 \pm 0.25$ & $0.000 *$ \\
\hline 9.Separate sharp wastes by good manner & $0.00 \pm 0.00$ & $0.10 \pm 0.30$ & $0.000 *$ \\
\hline 10.Disposal of sharp wastes in sharp box & $1.00 \pm 0.00$ & $1.00 \pm 0.00$ & \\
\hline
\end{tabular}

$*=$ Statistical significant difference $(p<0.05)$

Table (7): Total mean score of Health Team practice regarding infection control precautions in the following stated procedure.

\begin{tabular}{|l|c|c|c|c|}
\hline & \multirow{2}{*}{ Total } & $\begin{array}{c}\text { Nurses } \\
(\mathbf{n = 2 0 2})\end{array}$ & $\begin{array}{c}\text { Physicians } \\
(\mathbf{n = 3 1})\end{array}$ & \multirow{2}{*}{ P-value } \\
\cline { 3 - 5 } & & Mean \pm SD & Mean \pm SD & \\
\hline 1-Suction care & 22 & $17.89 \pm 0.56$ & $15.58 \pm 1.98$ & $0.000^{*}$ \\
\hline 2-Intubated patient care & 20 & $15.80 \pm 0.69$ & $14.45 \pm 1.48$ & $0.000^{*}$ \\
\hline 3-Total score of practice & 42 & $33.68 \pm 1.24$ & $30.02 \pm 3.45$ & $0.000^{*}$ \\
\hline
\end{tabular}

$*=$ Statistical significant difference $(p<0.05)$ 


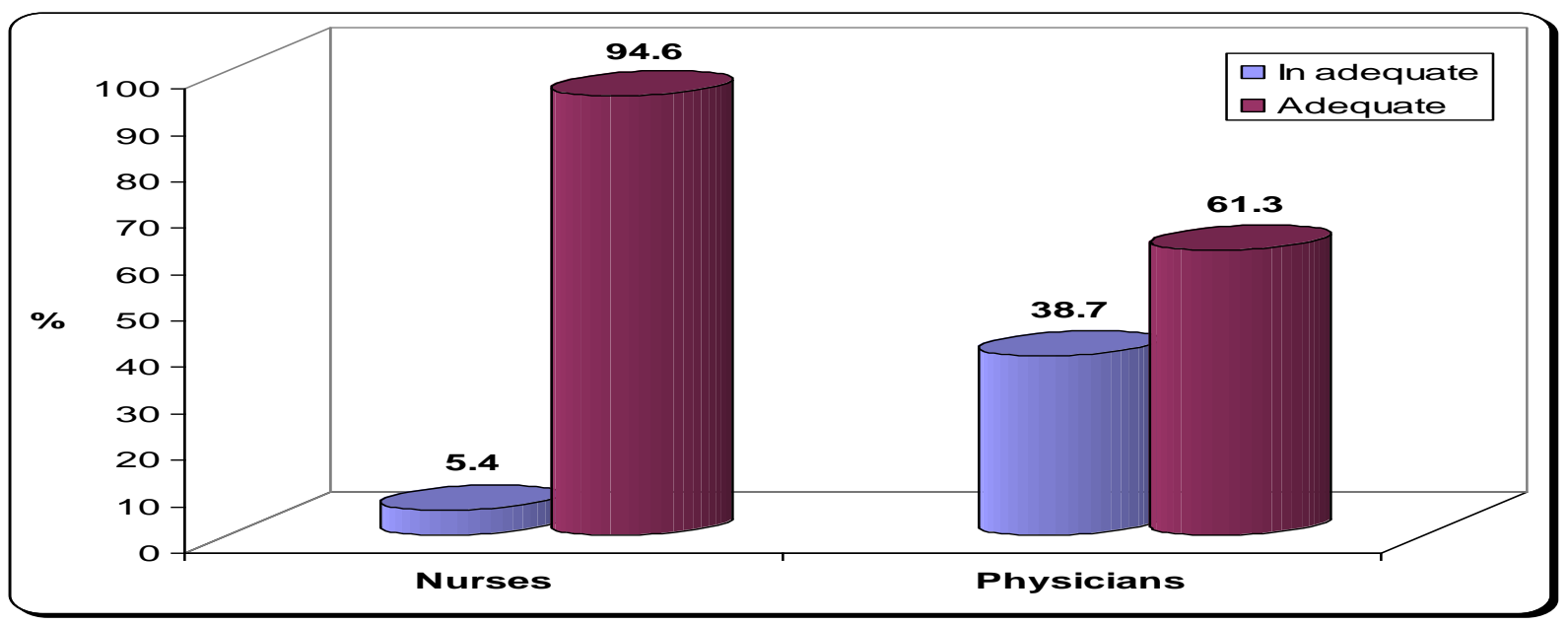

Figure (1): Total health Team practice level regarding infection control precautions

Table (I): demonstrated that; there is significant statistical difference in the demographic characteristics of nurses, physicians, and workers related to "age, sex, marital status, and years of experience" with P-value ( $\mathrm{p}<0.000 *)$.

Table (2): shows that; there is significant statistical difference in the administration of viral hepatitis B vaccine to the health team through the infection control program and the number of vaccination doses with P-value $(\mathrm{p}<0.000 *$ and $\mathrm{p}<0.037 *$ respectively).

Table (3): This table shows that; there is significant statistical difference between the number of nurses, physicians, and workers as regard injury with a needle while working, the cause of injury, and the reporting of recent needle stick injury before disposal with P-value $\left(\mathrm{p}<0.000^{*}\right)$. Also, there are significant statistical difference between the number of nurses, physicians, and workers as regard injury with a needle while working, and during insertion of the needle into the rubber stopper with $\mathrm{P}$-value ( $\mathrm{p}<0.009^{*}, \& \mathrm{p}<0.001 *$ respectively).

Table (4): This table shows that; there is significant statistical difference between the number of nurses, physicians, and workers as regard the following items presence of sinks for hand washing with Pvalue ( $\mathrm{p}<0.000 *$ and $\mathrm{p}<0.008 *$ respectively), and the availability of soap, antiseptic solution for healthy or surgical hand washing, availability of alcohol for hands rub, and safety box to get rid of sharps waste, presence of a policy for invasive procedures, with $\mathrm{P}$ value $\left(\mathrm{p}<0.000^{*}\right)$.

Table (5): This table shows that; there is significant statistical differences between the practice mean score of the nurses and physicians as regarding infection control precaution in the following items practice (2-5 items) and from (6-9 items), with Pvalue $\left(p<0.000^{*}\right)$. Also there is significant statistical differences between the nurses and physicians as regard (item 10) with $\mathrm{P}$-value $(\mathrm{p}<0.010 *)$. While the practice of health team regarding (item 1) and (item 11 ) was done correctly with percentage $(100 \%)$.

Table (6): This table shows that; there is significant statistical differences between the practice mean scores of nurses and physicians as regard infection control precaution in the following items (2-9), with $\mathrm{P}$-value $(\mathrm{p}<0.000 *)$. Also there is significant statistical differences between the practice of nurses and physicians as regard (item 7), with P-value $(\mathrm{p}<0.010 *)$.

Table (7): This table shows that; there is significant statistical differences between the practice mean score of the nurses and physicians as regard from (item 1) and (item 2) with P-value ( $<<0.000 *)$.

Figure (1): This figure shows that; there is a significant statistical difference between the practice of the nurses and physicians as regard adequacy of their practice regarding infection control precautions $(61.3 \% \quad \& 94.6 \%)$ respectively with P-value $(\mathrm{p}<0.000 *)$.

\section{Discussion}

Health care professionals are constantly exposed to microorganisms. Many of which can cause serious infections. Nurses in particular are often exposed to various infections during the course of carrying out their nursing activities (Fashafsheh et al., 2015)

Severely ill patients have a greater risk of acquiring nosocomial infections; this problem is greatest in critical care units. Therefore, healthcare professionals have an obligation to follow scientifically accepted for infection control to prevent disease transmission among patients and healthcare professionals (Adly et al., 2014)

Nurses and other health care workers play a key role in reducing the spread of disease, minimizing 
complications, and reducing adverse outcomes for their patients. Precautions are designed to protect healthcare professionals and patients from exposure to potentially infected blood and body fluids by applying the fundamental principles of infection prevention. (Lynn, 2015)

Teaching and training are essential for the nursing staff members to improve the quality of health care and to acquire new knowledge and skills (Abolwafa et al., 2013). Therefore, the aim of the current study is to assess the application of infection control precautions among health care team in intensive care units at Assiut University Hospital.

Assessment the information of health team in intensive care units regarding infection control precautions.

Demographic data about health team in intensive care units

The current study revealed that more than half of nurses were <25years, the vast majority of them were females and more than half were married. There was significant statistical difference in the number of nurses, physicians, and workers related to age, sex, marital status, and years of experience. This finding is in concordance with that of Budnyak et al., (2012) \& Shehata, (2011) who found that there were significant statistical differences in age and sex of the health care team included in the study. Similarly Abolwafa et al., (2013) have concluded that there was significant statistical difference in age and years of experience of the health care team included in the study. Other findings are in agreement with Shinde \& Mohite, (2014) who stated that the majority of staff nurses were belonging to the age group (19-25 years) but three-quarters of staff nurses were females and less than quarter of staff nurses were males.

Health team information about vaccination against viral hepatitis (B)

The current study revealed that less than half of nurses and more than half of physicians and workers were vaccinated against viral hepatitis (B). Also there was significant statistical difference in the number of nurses, physicians, and workers related to number of vaccination doses. These findings were more or less in agreement with Eskander et al., (2013) who reported that the majority of $\mathrm{HCW}$ s received vaccination against hepatitis $B$ viral infection for prevention of hospital-acquired infections of $\mathrm{HBV}$ as a pre-exposure immunization. In agrrement with the current study Fashafsheh et al., (2015) and Abd ElAziz et al., (2012) reported that vast majority of nurses received hepatitis $B$ vaccination due to the presence of hospital policies and there was significant statistical difference in HCWs received the three full doses of HBV vaccine.
Health team information about exposure to sharp injury during work

The current study revealed that around three quarter of nurses, and more than half of physicians, and workers were exposed to needle stick injury during work. Needle stick injury (NSIs) occurred mostly during the preparation of medication. This finding was more or less similar to that reported by Hanafi et al., (2011) who found that NSIs among HCWs mostly occurred during use of the device, and before disposal of needle. Similarly Eskander et al., (2013) have concluded that there was high significante statistical differences between the three groups of nurses' bachelor degree, diploma \& diploma with speciality in relation to NSIs. These results were in agreement with Eljedi, and Dalo, (2014) who stated that more than half of HCPs had been injured by needles or sharp medical instruments due to lack of knowledge of infection control and heavy workload.

The availability of supplies and resources in ICUs as represented by health team

The current study revealed that more than half of nurses and physicians and less than quarter of workers reported the presence of adequate number of sinks for hands hygiene. This result disagrees with Ali, (2005) who reported the insufficient infection control supplies and equipments.

The current study revealed that around more than half of nurses and less than quarters of physicians and workers reported the insufficiency of soap to hands hygiene beside sinks. Also there was significant statistical difference between the tested groups in this item. Similarly these results were in agreement with Wasswa et al., (2015) who reported inadequacy of soap and infection control supplies in the ICUs.

The current study revealed that around less than quarter of nurses, physicians and workers reported that alcohol hand gel is not available at 'point of care' for hand hygiene. This result was in accordance with Wasswa et al., (2015) who reported that the most commonly inadequate supplies were hands disinfectants in the ICUs.

The present study revealed that around less than half of nurses and less than quarter of physicians and workers reported the insufficiency of alcohol for hands hygiene, with significant statistical difference. This result was in accordance with Wasswa et al., (2015) who reported the presence of inadequate supplies of infection control and the least available items in hand hygiene were alcohol.

The current study revealed that around quarter of nurses and less than quarter of physicians reported the presence of sufficient amount of appropriate antiseptic solution for disinfection of the patient's skin, with no significant statistical difference. This result disagrees with Hassan et al., (2015) who stated 
that the vast majority of HCWs clean patient's skin with an appropriate antiseptic solution \& have knowledge about infection control.

In the present study the vast majority of nurses and workers and less than half of physicians reported the presence of a safety box to get rid of sharp wastes. This finding was more or less similar to that reported by Hanafi et al., (2011) who reported the adequacy of safety box in the ICUs to get rid of sharp wastes.

The present study revealed that around more than half of nurses and more than quarter of physicians reported the presence of a policy for invasive procedures, with significant statistical differences between the tested groups. This result was in accordance with O'Mahony, (2012) who reported the availability of verbal or written policy. As well Omar, (2015) mentioned that there were written and approved policies for infection control in ICUs. However, this finding disagrees with Adly et al, (2014) who mentioned that the vast majority of the studied sample reported the absence of written infection control guidelines.

Health team practice concerning the infection control precautions in intensive care units.

Health team practice in suction care

The present study revealed that there was significant statistical difference between the number of nurses and physicians regarding suction care and disposal of sharps. In relation to wastes and sharp disposal, all HCW used safety box correctly for disposal of sharps. This finding was in accordance with Tarko, (2014) who reported that the vast majority of HCWs had done $(100 \%)$ correctly the proper disposal of suction catheter and sharp wastes in safety box.

In the present study, there was a significant statistical difference between the number of nurses and physicians as regard wearing new gloves and using sterile device or equipment. This result was in accordance with Sole et al., (2003) who reported that more than half of HCWs change gloves before closed-system suctioning. Similarly Lima et al., (2013) reported the compliance of aseptic techniques by nurses and physicians when opening the catheter package.

Health team practice about intubation patient care

In the present study there was significant statistical difference between the number of nurses and physicians as regard the wearing of new gloves before the procedure. Similarly Abd El-Aziz, (2014) reported that there was significant statistical difference between the HCT in wearing gloves. This finding was in accordance with Al-Qadi, (2015) who reported that there was significant statistical difference in the wearing personal protective equipments between the studied nurses and physicians

In the present study there was no significant statistical difference in the number of nurses and physicians as regard hand washing or disinfection before procedure. This result was in accordance with Abd El-Aziz, (2014) who reported the same finding. This finding disagrees with Al-Qadi, (2015) who stated that there was significant statistical difference between the tested groups in performance of hand hygiene.

Total score of Health Team practice level regarding infection control precautions

In the present study, there was significant statistical difference between the number of nurses and physicians as regard suction care, intubated patient care and total score of practice. This result was in accordance with Eskander et al., (2013) who reported that there was a significant statistical difference in a mean total performance scores between the studied samples. This result was in accordance with Fashafsheh et al, (2015) who reported that assessment of nurses' practice regarding infection controls demonstrated that, the majority of the studied sample had good practice level of infection control.

Health Team practice regarding infection control precautions

The current study demonstrated that, there is a significant statistical difference between the number of nurses and physicians for the practice regarding infection control precautions. This finding was in accordance with Ahmad et al., (2012) who reported that there was significant statistical difference between the studied samples in the adequate practice. In addition, this finding was in accordance with Eskander et al., (2013) who reported that there was adequate performance level regarding infection control precautions. This finding disagrees with Khadoura et al., (2014) who demonstrated that less than half of physicians and less than quarters of nurses had adequate level of performance, while none of the workers had satisfactory level of practice.

As well Fashafsheh et al, (2015) emphasized that work places should have written policies about methods of utilizing infection control precautions to provide guidance on all aspects of critically ill patients' care. As well, continuing education regardless of age can significantly improve infection control practices and reduces infection.

\section{Conclusion}

Based on the results of the present study, it can be concluded that

- Critical care nurses in the current study have satisfactory practice level regarding infection 
control precautions and significant statistical differences of total score of practices.

- The majority of health team exposure to injury with a needle while working in ICUs and mostly that happens during the preparation of medication, while for physicians occurs during patients movements and for workers occurs during collection of hazardous sharp wastes.

\section{Recommendations}

- Availability of all facilities and equipments are required for applying precautions of infection control.

- Strict observation of nurses compliance / practice/ utilization of precautions of infection control by infection control team is needed.

- Continuous updating knowledge and practice of ICU health care team in-service educational programs are required.

- Availability of posters for reminding nurses to comply with precautions are recommended.

Recommendations for further researches

- Replication of the study on a large probability of sample from different ICUs is required.

- Study the factors predisposing to lack of compliance with infection control precautions in the ICUs is needed.

- Exploring the relationship between knowledge, previous exposure, and compliance of infection control precaution guidelines is important.

\section{References}

1. Abd El-Aziz A., (January 2014): effect of educational program on nurse's knowledge and skills about oral care for traumatized patients, AL-Azhar Assiut Medical Journal, AAMJ, Vol (12), No (1), 34-35.

2. Abd El-Aziz R., Ghalla A., Morsy M., \& Rus F., (2012), assessment of personal hygiene practice \&safety measures among government hospitals staff in Beniswiff governorate.

3. Abolwafa F. N., Ouda E. W., Mohammed Z. F., and Masoed S. E., (2013): Developing educational program for Nurses' Related to Infection Control of Invasive Procedures in Neonatal Units at EL-Minia University and General Hospitals, Journal of American Science, 9(10): [286-293]. (ISSN: 1545-1003). Available at http://www.jofamericanscience.org.

4. A Budnyak M., Gurevich J., Fabrikant K., Miller K., \& Puttaiah, (2012): dental infection control and occupational safety in the Russian federation, the journal of contemporary dental practice, 13(5): 705-710. Available at "www.the jcdp.com".
5. Adly M.., Amin M., \& Abd El Aziz A., (2014): Improving Nurses' Compliance with Standard Precautions of Infection Control in Pediatric Critical Care Units, Pediatric Nursing Department, Faculty of Nursing, Mansoura University, Mansoura, Egypt, World Journal of Nursing Sciences, available at E-mail f.amin@mu.edu.sa.

6. Ahmad R., Khamis M., Younis M., \& Alrady A., (September 2012): Effect of a developed educational booklet about standard infection control precautions on nurses' knowledge and practices at woman's health center-Assiut University Hospital, Egypt, Medical Journal Cairo University, Vol.80, No. 1,: 435-445, available at "www.medicaljournalofcairouniversity.com".

7. Ali G., (2005): establishing standards for prevention of nosocomial infection in the recovery rooms \&surgical ward at El-Minia university hospital, doctoral degree, critical care nursing, and faculty of nursing, university of Assiut, 71-107.

8. Al-Qadi H., (2015): impact of educational training program on nurse's performance for patient undergoing endotracheal tube at Assiut university hospital, master degree, critical care nursing, faculty of nursing, Assiut University, 5878.

9. Benson S., \& Powers J., (2011): your role in infection prevention, Lippincott,page36. Available "www.NursingMadeIncrediblyEasy.com"

10. Burd M., Ruddy R., \& Infection Control Nurses Association, (2014): Infection control,12.

11. Centers for Disease Control and Prevention and the Healthcare Infection Control Practices Advisory Committee (CDC and HICPAC), (2014): guide to infection prevention for outpatient setting minimum expectations for safe care, 6-12, available at: "http://www.cdc.gov/HAI/prevent/prevent_pubs.h tml".

12. Creed F., \& Spiers C., (2010): Care of the acutely ill adult-an essential guide for nurses, Oxford, chapter 14, 454-261.

13. Correa I., Moralejo D., Barretti P., and El Dib R., (2013): Interventions to improve adherence to guidelines on 'Standard Precautions' for the control of healthcare-associated infections (Protocol), The Cochrane Collaboration, Published by John Wiley \& Sons, Ltd, Issue 10, 3. "DOI: 10.1002/14651858.CD010768".

14. Eljedi A., \& Dalo S., (2014): Compliance with the National Palestinian Infection Prevention and Control Protocol at Governmental Paediatric 
Hospitals in Gaza Governorates, Sultan Qaboos University Medical Journal. 14(3): e375-e381, PMCID: PMC4117664.

15. Eskander G., Morsy M., \& Elfeky A., (2013): Intensive care nurses' knowledge \& practices regarding infection control standard precautions at a selected Egyptian cancer hospital, Journal of Education and Practice, Vol.4, No.19, 160-164. Available at: hanaa_elfeky@yahoo.com

16. Evans L., Sunley K., Gallagher R., \& Barrett S., (2012): Essential practice for infection prevention and control Guidance for nursing staff, Royal College of Nursing, 3- 30. Available at" www.rcn.org.uk"

17. Fashafsheh I., Ayed A., Eqtait F., \& Harazneh L., (2015): knowledge and practice of nursing staff towards infection control measures in the Palestinian hospitals, Journal of Education and Practice, Vol.6, No.4, 80-88. Available at "http://www.iiste.org/journals/"

18. Hanafi I., Mohamed M., Kassem S., \& Shawki M., (2011): needle stick injuries among health care workers of University of Alexandria hospitals, Eastern Mediterranean Health Journal, department of Community Medicine, department of Obstetrics and Gynecology, Faculty of Medicine, University of Alexandria, Alexandria, Egypt, Vol. 17, No. 1, 4. Available at (Correspondence to A.M.Mohamed: aida_mohey@yahoo.cm)

19. Hassan A., Gabal S., Dewedar A., \& Mostafa S., (2015): assessment of infection control practice and knowledge of health care workers regarding needle stick injuries in / a private hospital-Cairo-Egypt.

20. Khadoura K., Afifi S., \& Aljeesh Y., (2014): environmental infection control in intensive care units at Gaza Governorates: KAP Study, Journal of Biology, Agriculture and Healthcare, Vol.4, No.27, 301-308. Available at: "k.khadourah@gmail.com" "http://www.iiste.org/journals/"

21. Lima D., Fleck S., Borges J., Condessa L., \& Vieira R., (2013): Effects of educational intervention on adherence to the technical recommendations for tracheobronchial aspiration in patients admitted to an intensive care unit, 25(2):115-122. Available at rlcondessa@ gmail.com. DOI: 10.5935/0103-507X.20130022.

22. Lynn P., (2015): Taylor's clinical nursing skills a nursing process approach, Wolters Kluwer, fourth edition, 1, 407-620, 778, 807-810, and 954-985.

23. Ministry of Health \& Population, (2014): Central Department for Preventive Affairs, Infection Control Department, and The national program to fight infection.
24. O'Mahony D., (2012): Infection control in general practices in Buffalo City and OR Tambo District Municipalities, South Africa, 2. available at "donomahony@gmail.com"

25. Omar A., (2015): assessment of infection control measures in primary health care units in Assiut governorate, master degree, faculty of medicine, Assiut University, public health and community medicine.

26. Sarani H., Balouchi A., Masinaeinezhad N.\& Ebrahimitabs E., (2016): Knowledge, Attitude and Practice of Nurses about Standard Precautions for Hospital-Acquired Infection in Teaching Hospitals Affiliated to Zabol University of Medical Sciences (2014), Global Journal of Health Science, Canadian Center of Science and Education, 193-196.

27. Shehata B., (2011): assessment of nurses' practices related to infection control during vaccination in children at El-Minia, master degree, pediatric nursing, 61-81.

28. Shinde B., \& Mohite R., (2014): A Study to Assess Knowledge, Attitude and Practices of Five Moments of Hand Hygiene among Nursing Staff and Students at a Tertiary Care Hospital at Karad, International Journal of Science and Research, 1-

29. Sole L., Byers F.J., Ludy E.J., ZhangY., Banta M., \& Brummel K., (2003): A Multisite Survey of Suctioning Techniques and Airway Management Practices, the American Association of Critical-Care Nurses.

30. Tarko S., (2014): assessment of the knowledge, attitude and practice of fourth, fifth and sixth year medical students on Standard precaution in Tash, Addis Ababa, Ethiopia, master of emergency medicine and critical care, 35-38.

31. World Health Organization, (2014): Infection prevention and control of epidemic- and pandemic-prone acute respiratory infections in health care, Geneva, 1-26, 44-48. Available at (http:// whqlibdoc. who.int/publications/2009/9789241597906_eng.p df).

32. Woodrow p., (2012): Intensive care nursing, Rout ledge, third edition, chapter 15, 131-134.

33. Wasswa P., Nalwadda K. C., Buregyeya E., Gitta N., Anguzu P., \& Nuwaha F., (2015): Implementation of infection control in health facilities in Arua district, Uganda: a crosssectional study, Bio Med Central, US National Library of Medicine, National Institutes of Health, 4-7. 